\title{
KEMISKINAN, PENGANGGURAN DAN KETIDAKADILAN SOSIAL
}

\author{
Roy Charly HP Sipahutar \\ Institut Agama Kristen Negeri Tarutung \\ Email: roycharlygpp@ gmail.com
}

\begin{abstract}
Abstrak: Kemiskinan, Pengangguran dan Ketidakadilan Sosial adalah isu klasik yang harus selalu dipergumulkan dalam setiap era. Tulisan ini berupaya untuk menggambarkan situasi kekinian kita di Indonesia yang tentunya tentang ketiga tema tersebut. Upaya pemerintah untuk mengentaskan kemiskinan belum mencapai tahap yang memuaskan, sehingga perlu kepedulian bersama untuk mempergumulkannya. Selanjutnya akan dipaparkan juga bagaimana pandangan kekristenan yang alkitabiah terhadap Kemiskinan, Pengangguran dan Ketidakadilan Sosial yang sedang kita hadapi. Dan di bagian akhir penulis akan menawarkan bagaimana sebaiknya melakukan pengentasan pengangguran, kemiskinan dan mewujudkan keadilan sosial.
\end{abstract}

Kata Kunci: Kemiskinan, Pengangguran, Ketidakadilan Sosial.

\begin{abstract}
Poverty, Unemployment and Social Injustice are classic issues that must always be struggled in every era. This paper seeks to describe our current situation in Indonesia, which is certainly about the three themes. The government's efforts to alleviate poverty have not yet reached a satisfying stage, so that mutual care needs to be taken to improve it. Furthermore, we will also explain how the biblical Christianity view of poverty, unemployment and social injustice that we are facing. And at the end of the article the author will offer how to eradicate unemployment, poverty and realize social justice.
\end{abstract}

Key Words: Poverty, Unemployment, Social Injustice.

\section{PENDAHULUAN}

Kemiskinan, pengangguran dan ketidakadilan sosial merupakan masalah global, yang usianya sama tuanya dengan sejarah manusia itu sendiri, khususnya dialami oleh negara-negara yang sedang berkembang (nama lain yang dipopulerkan oleh belahan Eropa untuk memerhalus sebutan bagi negara-negara miskin). Indonesia misalnya, era krisis ekonomi tahun 1997-1998 yang telah melahirkan buah pahit berupa kemiskinan dan penganguran, hal yang masih saja sebagai permasalahan yang belum terselesaikan hingga hari ini. Angka statistik tetap memberikan informasi bahwa masih banyak jumlah penduduk yang berkutat dalam kelompok masyarakat miskin. ${ }^{1}$ Persoalan

\footnotetext{
${ }^{1}$ Badan Pusat Statistik (BPS) mewartakan data resmi bahwa jumlah penduduk miskin (penduduk yang berada di bawah Garis Kemiskinan di Indonesia pada Bulan Maret 2008 yang berjumlah 34,96 juta (15,42 persen), Maret 2009 sebanyak 32,53 juta $(14,15$ persen), Maret 2010 sebanyak 31,02 juta $(13,33 \%)$. Walaupun data terkini pada bulan Maret 2018 menurun
}

yang sedang terjadi bukan hanya terletak dalam minimnya kesempatan kerja dan semakin banyaknya perusahaan/ industri yang gulung tikar (tutup) sehingga menyebabkan banyak karyawan diberhentikan (PHK); tetapi juga tingginya biaya hidup dan kebutuhan di tengah-tengah masyarakat oleh karena harga barang dan jasa yang terkadang tidak stabil. Akses penghidupan layak yang terbatas juga menjadi problematika lain.

Karena itu persoalan ini menjadi agenda utama setiap pemerintah dalam setiap periode kepemimpinan. Misalnya dalam Nawacita pemerintahan Presiden Joko Widodo, kesadaran penuh akan bahaya kemiskinan dan pengangguran ini "memaksa" untuk merumuskannya dalam bagian tersendiri khususnya pada poin 6 dan

menjadi 25,95 juta orang (9,82 persen), berkurang sebesar 633,2 ribu orang dibandingkan dengan kondisi September 2017 yang sebesar 26,58 juta orang (10,12 persen). Tidak dapat dimungkiribahwajumlahitumasih sangat besar. 
7. ${ }^{2}$ Yang aktual, pada tahun politik 2019 ini pun isu tersebut sepertinya menjadi "jualan" wajib bagi para pihak yang mencalonkan diri menjadi Presiden ataupun menjadi anggota legislatif. Masing-masing mengangkat kemiskinan dan pengangguran sebagai tema utama dalam pameranpameran keunggulan masing-masing. Kita mengerti slogan kampanye mereka ini tidak sedikit yang hanya bersifat slogan atau gincu pinang di bibir merah, atau sekadar kelatahan imitatis hampa substansi. Tetapi kita tahu ada pula yang tulus, bertitik tolak dari tanggung jawab moral dan komitmen ideologis, bahwa pembangunan nasional adalah proses humanisasi, proses pencerdasan hidup rakyat, bukan sekadar pencerdasan logika dan memori.

Di pihak lain, tampaknya keterpanggilan gereja sebagai institusi ataupun umat Kristen sebagai bagian komunitas maupun personal untuk turut serta bergumul secara nyata dan konsisten dalam persoalan-persoalan sosial masih jauh dari apa yang diharapkan. Sejarah mencatat sampai abad 19 gereja dianggap sebagai takhta suci yang tidak boleh membicarakan sosial masyarakat, hal inilah yang melahirkan gerakan di Jerman pada paruh akhir abad 19 untuk menyadarkan bahwa setiap hal adalah dunia pergumulan gereja. ${ }^{3}$ Sehingga dengan demikian maka teologi tidak melulu melakukan penyelidikan teks

\footnotetext{
${ }^{2}$ Salah satu kriteria keberhasilan pembangunan nasional adalah penurunan jumlah masyarakat miskin. Pantjar Simatupang dan Saktyanu K. Dermoredjo, Produksi Domestik Bruto, Harga, dan Kemiskinan, dalam Media Ekonomi dan Keuangan Indonesia, Vol. 51 No. 3, h. 191-192. Nawacita: 6. Meningkatkan produktivitas rakyat dan daya saing di pasar internasional sehingga bangsa Indonesia bisa maju dan bangkit bersama bangsa-bangsa Asia lainnya. 7. Mewujudkan kemandirian ekonomi dengan menggerakkan sektor-sektor strategis ekonomi domestik.

3 Pada tahun 1980, Adolf von Harnack dan teman-temannya mendirikan Kongres Sosial Protestan di Berlin-Jerman yang dimaksudkan sebagai forum untuk mendiskusikan keterlibatan orang Kristen dalam masalah-masalah masyarakat. Binsar Nainggolan, Pengantar Etika Terapan, (Pematang Siantar: L-SAPA, 2007), h. 2829.
}

dan ritual, dogmatis dan perihal kelembagaan semata, namun ia harus mampu menjawab tantangan dalam pergumulan sosial dimana ia hidup dan mengontekskan diri. Teologi menjadi dasar iman untuk bertindak nyata mengentaskan persoalan sosial yang terjadi di masyarakat. ${ }^{4}$

\section{Pengangguran, Kemiskinan dan Urbanisasi Sebagai Dilema Sosial}

Kita menyadari bahwa modernisasi, globalisasi dan perkembangan Iptek ternyata membawa pengaruh yang luar biasa dalam perjalanan dunia ini. Oleh karena perkembangan dan kemajuan tersebut, masyarakat mengharapkan akan terjadi perubahan yang lebih baik. Artinya setiap orang berharap dapat memperbaiki pendapatan melalui pekerjaan, merubah status sosial ekonomi dan lain-lain. Hal itu mengakibatkan tingginya angka urbanisasi dari desa (yang dikatakan miskin) ke kotakota besar yang pertumbuhan ekonominya pesat oleh karena pertumbuhan industri yang tinggi.

Sensus penduduk yang dilaksanakan dalam periode tertentu selalu saja mendeskripsikan bahwa cukup besar penduduk Indonesia yang dapat didefenisikan sebagai kaum migran, ${ }^{5}$ yang mencoba mencari keberuntungan dengan memerbaiki status sosial ekonomi dan kehidupan keluarga, walau tidak ada kepastian bahwa dengan migran ke kota besar akan membawa perubahan ke arah yang diharapkan. Hal ini terbukti dengan semakin banyaknya migran yang memasuki kota Jakarta pada setiap musim lebaran, dan diperkirakan kepadatan penduduk membawa malapetaka besar yang membuat sebagian besar penduduk Jakarta harus bertempat tinggal di tepi-tepi sungai, jembatan, pinggir-pinggir jalan dan lain sebagainya. ${ }^{6}$

\footnotetext{
${ }^{4}$ Seperti apa yang diutarakan Karl Barth bahwa keberadaan gereja adalah melayani dunia dalam sejarah, gerja sebagai tubuh Kristus yang hidup dalam konteksnya sendiri dan harus menjawab tantangan konteks tersebut. Karl Barth, Church Dogmatics (IV), (Edinburgh: T\&T Clarck Ltd., 1962), h. 681-682.

${ }^{5}$ Bnd. Graeme J. Hugo, "Migrasi Sirkuler", dalam Dorodjatun Kuntjoro-Jakti (ed.), Kemiskinan di Indonesia (Jakarta: Yayasan Obor Indonesia, 1986), h. 57.
} 
Banyak di antara migran yang mencoba bertahan untuk beberapa lama, dan pada akhirnya akan kembali ketika tidak berhasil. Migran seperti ini sering disebut migran sirkuler. Kebanyakan kaum migran sirkuler yang berasal dari desa yang diamati itu mendapat pekerjaan di sektor ekonomi perkotaan informal yang bersifat padat karya, dimana produksinya rendah. Hal itu dipengaruhi beberapa hal; pertama, kerja yang demikian lebih cocok dengan sifat migran sirkuler, tidak seperti sektor formal yang menghendaki orang bekerja enam hari seminggu. Kedua, jauh lebih mudah memasuki sektor informal, sebagaimana sistem pertanian tradisional Jawa. ${ }^{7}$

Sebab-sebab utama

orang

meninggalkan pedesaan berhubung dengan susahnya mendapat pekerjaan di wilayah pedesaan. Daya tarik tradisional, seperti misalnya kemungkinan mendapat pekerjaan dengan upah lebih tinggi, kehidupan kota yang penuh gairah, kesempatan pendidikan yang baru, dan sebagainya, ${ }^{8}$ menjadi alasan utama migrasi besar-besaran ke kota. Meskipun mereka miskin, para migran yang datang ke kota umumnya bernasib lebih baik daripada ketika mereka masih berada di pedesaaan. ${ }^{9}$ Pandangan dan pemahaman ini ternyata dituturkan kepada orang lain yang juga menginginkan kehidupan yang lebih baik. Rangsangan migrasi semakin kuat

\footnotetext{
${ }^{6}$ Angka urbanisasi adalah sebesar 4,1 persen, lebih tinggi daripada pertumbuhan urbanisasi di Tiongkok 3,8 persen dan India 3,1 persen. Kemiskinan merupakan faktor pendorong para migran meninggalkan daerah asal menuju ke daerahdaerah yang memiliki lebih banyak kesempatan memperoleh sumber daya sosial ekonomi. Suatu "lingkaran setan" yang harus diputus. A.S. Oberai, State Policies and Internal Migration: Studies in Market and Planned Economies, (London: Croombelm, 1985).

${ }^{7}$ GraemeJ.Hugo, “Migrasi Sirkuler”, h. 67-68.

${ }^{8}$ Gordon Temple, "Migrasi ke Jakarta", dalam Dorodjatun Kuntjoro-Jakti (ed.), Kemiskinan di Indonesia (Jakarta: Yayasan Obor Indonesia, 1986), h. 84.

${ }^{9}$ Gustav Papenak, "Penduduk Miskin di Jakarta", dalam Dorodjatun Kuntjoro-Jakti (ed.), Kemiskinan di Indonesia (Jakarta: Yayasan Obor Indonesia, 1986), h. 230.
}

sebab di kalangan penduduk miskin dalam semua bidang pekerjaan terdapat orangorang yang berhasil. ${ }^{10}$

Karena itu, kota-kota besar akhirnya menjadi pusat tenaga kerja yang mengharapkan pekerjaan yang lebih baik, sehingga pengangguran dan kemiskinan berkembang dengan sangat pesat. Di sisi lain, ketidakadilan sosial semakin tinggi dengan memperhatikan pengangguran dan kaum miskin yang hidup menderita sedangkan para pengusaha dan penguasa (elit politik) semakin makmur dan menutup diri terhadap masyarakat di sekitarnya. Perbedaan status, gaya hidup, pendapatan dan sosial ekonomi tidak bisa dihindarkan. Kaum miskin akan berpeluang besar tetap miskin dan yang kaya akan semakin kaya, sehingga angka kemiskinan sulit sekali bisa ditekan bahkan dapat saja meningkat dari tahun ke tahun.

Pengangguran merupakan persoalan penting yang membutuhkan pemahan lanjutan dalam pokok meningkatkan kesejahteraan rakyat. Sangatlah tidak mungkin akan tercapai masyarakat yang adil dan sejahtera sementara angka pengangguran setiap tahun terus meningkat. Secara umum menurut pengamatan saya ada tiga hal yang menjadi penyebab utama terjadinya pengangguran, yaitu:

1. Jumlah lapangan kerja yang tersedia lebih kecil dari jumlah pencari kerja.

2. Kompetensi pencari kerja tidak sesuai dengan pasar kerja.

3. Pengangguran juga disebabkan oleh pemutusan hubungan kerja (PHK).

Sementara itu harus diakui pula bahwa kurangnya spesialisasi menyebabkan terjadinya pengangguran. Perusahaan dan dunia usaha lainnya lebih membutuhkan angkatan kerja dengan keterampilan/kemahiran dalam disiplin ilmu tertentu untuk suatu pekerjaan tertentu. Sangatlah tidak masuk akal, bahwa setiap angkatan kerja memiliki spesialisasi kemampuan kerja yang betul-betul menjawab semua tuntutan kerja. Artinya pada tahap ini, angkatan kerja masih mengutamakan tenaga bukan kemampuan berpikir dan keahlian tertentu.

\footnotetext{
${ }^{10}$ Gustav Papenak, "Penduduk Miskin di Jakarta", h. 231.
} 
Menurut Simon dan Christoper Danes, ada lima jenis pengangguran berdasarkan apa yang penyebabnya:

1. Pengangguran struktural.

Keadaan ini disebabkan oleh pemutusan hubungan kerja (PHK) oleh perusahaanperusahaan yang merugi/tutup oleh karena keadaan pasar dan ekonomi yang memburuk.

2. Pengangguran sementara.

Keadaan ini disebabkan oleh penundaan pindah kerja, dari suatu pekerjaan ke pekerjaan lainnya.

3. Pengangguran tidak tetap.

Jenis pengangguran ini disebabkan pekerjaan jangka pendek yang ada telah selesai dikerjakan. Misalnya pekerja bangunan, pertanian, dan lain-lain.

4. Pengangguran teknologis.

Pengangguran jenis ini disebabkan digantinya manusia dengan mesin yang serba otomatis.

5. Pengangguran residu.

Sekelompok orang yang benar-benar tidak mau bekerja. ${ }^{11}$

Angka pengangguran masih menjadi persoalan bangsa, hal ini kelihatan dari data statistik penduduk usia kerja yang belum terserap lapangan kerja. ${ }^{12}$ Dengan kira-kira dua juta penduduk Indonesia yang tiap tahunnya terjun ke dunia kerja, adalah tantangan yang sangat besar buat pemerintah Indonesia untuk menstimulasi penciptaan lahan kerja baru supaya pasar kerja dapat menyerap para pencari kerja yang tiap tahunnya terus bertambah.

Sementara itu, dalam Kamus Umum Bahasa Indonesia dicatat pengertian kemiskinan adalah tidak berharta serta berkekurangan dalam hidupnya, karena penghasilan yang rendah atau sangat rendah.

\footnotetext{
11 Simon dan Christoper Danes, Masalahmasalah Moral Sosial Aktual dalam Perspektif Iman Kristen, (Yogyakarta: Kanisius, 2000), h. 117.

12 Badan Pusat Statistik (BPS) mencatat per Agustus 2018 angka pengangguran di Indonesia sebesar $5,34 \%$ atau setara 7,001 juta orang. Sebagai informasi, angka pengangguran tersebut berasal dari pendidikan SMK sebesar 11,24\%, lulusan SMA sebesar 7,95\%, lulusan diploma $\mathrm{I} / \mathrm{II} / \mathrm{III}$ sebesar $6,02 \%$, Iulusan universitas sebesar $5,89 \%$, lulusan SMP sebesar $4,80 \%$ dan lulusan SD sebesar $2,43 \%$.
}

Secara umum, mereka yang miskin itu ialah orang-orang yang kekurangan sandang, pangan, pakaian, kebutuhan sehari-hari, perumahan, serta kehidupan yang sangat memrihatinkan. $^{10} \quad$ Kesadaran akan kemiskinan baru terasa pada waktu masyarakat ekonomi lemah memerhadapkan kehidupan mereka dengan masyarakat yang lebih tinggi taraf hidupannya, yaitu mereka yang mempunyai tingkat kehidupan sosial dan ekonomi yang lebih tinggi. Dengan demikian kemiskinan dapat didefenisikan sebagai suatu standar tingkat hidup yang rendah, yaitu adanya suatu tingkat kekurangan materi pada sejumlah orang dibandingkan dengan standar kehidupan yang umum berlaku dalam masyarakat yang bersangkutan. ${ }^{13}$

Dengan melihan ukuran/standar kemiskinan, maka kemiskinan ada dua bagian yaitu: "kemiskinan absolut" dan "kemiskinan relative". Kemiskinan absolut diukur dengan besarnya pendapatan perorangan pertahun sebagaimana sudah diaturkan oleh Bank Dunia. ${ }^{14}$ Standar garis kemiskinan Bank Dunia ada di kisaran USD 1,9 atau sekitar Rp. 27.000 dalam kurs saat ini $(1$ dolar $=\operatorname{Rp} 14.160 .00) .{ }^{15}$ Artinya, orang yang disebut Bank Dunia miskin bila pengeluarannya USD 1,9 per hari. Angka tersebut bisa saja setiap tahunnya terus

10 J.S.Badudu dan S.N.Zain, Kamus Umum Bahasa Indonesia, (Jakarta: Sinar Harapan, 1996), h. 903. Bakhit mendefenisikan kemiskinan sebagai keadaan yang memiliki wujud yang majemuk, termasuk rendahnya tingkat pendapatan dan sumber daya produktif yang menjamin kehidupan yang bersinambung;; kelaparan dan kekurangan gizi; rendahnya tingkat kesehatan; keterbatasan dan kurangnya akses kepada pendidikan dan layanan pokok lainnya; kehidupan bergelandang dan tempat tinggal yang tidak memadai; lingkungan yang tidak aman; serta diskriminasi dan keterasingan sosial. Kemiskinan juga dicirikan oleh rendahnya tingkat partisipasi dalam proses pengambilan keputusan dalam kehidupan sosial, sipil dan budaya. Izzedin Bakhit, Menggempur Akar-akar Kemiskinan, (Jakarta: Yakoma PGI, 2001), h. 5.

${ }^{13}$ Merphin Panjaitan, Memberdayakan Kaum Miskin, (Jakarta:BPK Gunung Mulia, 2002), h. 7. ${ }^{14}$ Bnd. I.J.Cairns, Perjanjian LamadanIndonesia yang Sedang Membangun, (Jakarta: BPK Gunung Mulia, 1999), h. 98.

${ }^{15}$ Kurs Dollar per 05 April 2019. 
meningkat. Sedangkan kemiskinan relatif diukur dari asupan gizi, pakaian, pemukiman dan perawatan medis yang minimal. Emil Salim mengemukakan, mereka yang hidup di bawah garis kemiskinan memiliki ciriciri: pertama, mereka umumnya tidak memiliki faktor produksi sendiri, seperti tanah yang cukup, modal ataupun keterampilan. Kedua, mereka tidak memiliki kemungkinan untuk memeroleh aset poduksi dengan kekuatan sendiri (tanah garapan, modal usaha dan sebagainya). Ketiga, tingkat pendidikan mereka yang rendah, tidak sampai tamat SD. Keempat, banyak di antara mereka yang tinggal di pedesaan dan tidak memiliki tanah. Kelima, banyak di antara mereka hidup di kota masih berusia muda dan tidak mempunyai keterampilan (skill) atau pendidikan. ${ }^{16}$

Kemiskinan dipahami dalam berbagai pandangan, pemahaman utamanya mencakup: pertama, gambaran kekurangan materi, yang biasanya mencakup kebutuhan pangan sehari-hari, sandang, perumahan, dan pelayanan kesehatan. Kemiskinan dalam arti ini dipahami sebagai situasi kelangkaan barang-barang dan pelayanan dasar. Kedua, gambaran tentang kebutuhan sosial, termasuk keterkucilan sosial, ketergantungan, dan ketidakmampuan untuk berpartisipasi dalam masyarakat. Hal ini termasuk pendidikan dan informasi.

Keterkucilan sosial biasanya dibedakan dari kemiskinan, karena hal ini mencakup masalah-masalah politik dan moral, dan tidak dibatasi pada bidang ekonomi. Dan yang ketiga, gambaran tentang kurangnya penghasilan dan kekayaan yang memadai. Makna "memadai" di sini sangat berbedabeda melintasi bagian-bagian politik dan ekonomi di seluruh dunia.

Kemiskinan struktural terjadi karena bahaya laten Korupsi, Kolusi, dan Nepotisme (KKN) yang merajalela pada masa Orde Baru yang lalu dan yang tidak tuntas sampai hari ini, menciptakan kondisi sedemikian rupa sehingga banyak orang menjadi miskin karena tidak mendapatkan sumber daya yang senantiasa mereka dapatkan, karena struktur kemasyarakatan

\footnotetext{
${ }^{16}$ Merphin Panjaitan, MemberdayakanKaum Miskin, h. 7-9.
}

dan kenegaraan yang menghalanginya. ${ }^{17} \mathrm{Di}$ sinilah ketidakadilan sosial semakin melebar dan jurang perbedaan semakin dalam antara golongan elit politik/ pemerintahan dan masyarakat miskin. ${ }^{18}$ Meskipun kemiskinan yang paling parah terdapat di dunia bekembang, akan tetapi ditemukan bukti bahwa kemiskinan hadir di setiap region. Di negara-negara maju, kondisi ini menghadirkan kaum tuna wisma yang berkelana ke sana- ke mari dan daerah pinggiran kota dan ghetto yang miskin. Kemiskinan dapat dilihat sebagai kondisi kolektif masyarakat miskin, atau kelompok orang-orang miskin, dan dalam pengertian ini keseluruhan negara kadang-kadang dianggap miskin. Untuk menghindari stigma ini, negara-negara ini biasanya disebut sebagai negara berkembang.

\section{Kemiskinan, Pengangguran dan Ketidakadilan Sosial dalam Pandangan Kristen}

Bangsa Indonesia menjungjung tinggi keadilan sosial sebagaimana yang tertuang dalam sila kelima Pancasila: Keadilan sosial bagi seluruh rakyat Indonesia. Menurut Suryawasita ada tiga prinsip keadilan yaitu keadilan atas dasar hak, keadilan atas dasar upah/jasa dan keadilan atas dasar kebutuhan. ${ }^{19}$ Hal yang sama juga dituangkan pada Pasal 33 UUD 1945 (pasal mengenai perekonomian)

\footnotetext{
17 Merphin Panjaitan, Memberdayakan Kaum Miskin, h. 13. Dapat pula dihubungkan dengan penyebab individual, atau patologis, yang melihat kemiskinan sebagai akibat dari perilaku, pilihan, atau kemampuan dari si miskin; penyebab keluarga, yang menghubungkan kemiskinan dengan pendidikan keluarga; penyebab subbudaya ("subkultural"), yang menghubungkan kemiskinan dengan kehidupan sehari-hari, dipelajari atau dijalankan dalam lingkungan sekitar; penyebab agensi, yang melihat kemiskinan sebagai akibat dari aksi orang lain, termasuk perang, pemerintah, dan ekonomi; penyebab struktural, yang memberikan alasan bahwa kemiskinan merupakan hasil dari struktur sosial.

18 Stott melihat hal ini dari perspektif sosial, miskin akibat penindasan, mereka adalah korban ketidakadilan serta ketidakberdayaan. Lihat John Stott, Isu-isu Global, (Jakarta: YKBK/OMF, 2010), h. 307-308.

19 A. Suryawasita, Asas Keadilan Sosial, (Yogyakarta: Kanasius, 1989), h. 26.
} 
diletakkan di Bab XIV UUD 1945 yang judulnya "Kesejahteraan Sosial". Dengan kata lain, perekonomian mau diapakan saja (sesuai ayat-ayatnya), "diotak-atik" manasuka, ujung-ujungnya harus membuahkan "kesejahteraan sosial".

Kemiskinan pengangguran, dan ketidakadilan sosial merupakan dilema etis yang menghantam hampir seluruh belahan dunia termasuk Indonesia. Masalah tersebut semakin menghimpit negara-negara berkembang oleh karena kebijakan negaranegara maju yang dengan bangga menunjukkan kuasa dan kekuatan ekonominya. Pengangguran, kemiskinan adalah musuh yang harus ditaklukkan, untuk itu kita mengemban tugas memajukan masyarakat yang sejahtera, adil dan makmur. Tuhan tidak menghendaki manusia hidup dalam kemiskinan dan kemelaratan, Dia mengijinkan berkat yang berkelimpahan agar setiap orang memeroleh kekayaan/penghidupan yang layak, makmur dan sejahtera. Pada awalnya Tuhan menciptakan segala sesuatu dengan baik dan sempurna, Tuhan berfirman: "Lihatlah aku memberikan kepadamu segala tumbuhtumbuhan yang berbiji di seluruh bumi; itulah akan menjadi makananmu" (Kej 1:29). Artinya, dalam konsep awal penciptaan tidak ada kemiskinan dan pengangguran karena segala sesuatu disediakan Tuhan untuk menjadi makanan (kesejahteraan) manusia. Ketika manusia jatuh ke dalam dosa perintah itu kembali dipertegas agar manusia (adamah: manusia tanah) itu mengolah tanah dan bekerja untuk kesejahteraan dan kemakmurannya (Kej 3:17-19).

Jika demikian, pesan pertama yang bisa ditangkap adalah Allah tidak menghendaki manusia hidup dalam kemiskinan. Pengangguran dan kemiskinan berkembang setelah peradaban manusia semakin maju dikemudian hari. Istilah orang upahan kemudian diperkenalkan dalam Im 25:39-40 (saudara yang jatuh miskin, menjadi orang upahan), inilah yang

\footnotetext{
${ }^{20}$ Amandemen tahun 2002 mengubah judul Bab itu menjadi "Perekonomian dan Kesejahteraan Sosial", menunjukkan telah terjadinya suatu pereduksian makna dan/ atau kedangkalan pemahaman mengenai cita-cita dari para perumusnya di MPR.
}

kemudian berkembang dalam pemakaian istilah budak atau pekerja. Namun pemakaian kata orang upahan dan budak dalam PL lebih mengarah kepada penjaminan kesejahteraan bersama, bukan pengembangan kemiskinan/pengangguran dengan memertajam ketidakadilan sosial.

PL justru menolak penindasan dengan suara-suara nabiah yang disampaikan oleh para nabi seperti Yeremia (7:6) Yehezkiel 18:12); Mika (2:2) Amos (5:11-12); Maleakhi (3:5) dan lain sebagainya. $^{21}$ Kitab Imamat bahkan mengatur hak-hak orang miskin dari hasil ladang, kebun dan pekerjaan seseorang (19:9-10). Dengan demikian, Tuhan sudah memerkenalkan hukum kasih dalam menjamin hak-hak orang lain, termasuk kesejahteraannya jauh sebelum Yesus Kristus datang. Memang dalam PL berkembang pemahaman bahwa setiap orang yang diberkati Tuhan hidupnya akan makmur dan mereka yang miskin, melarat, menderita penyakit adalah orang yang dikutuk Tuhan. Tetapi bukan berarti Tuhan tidak memberkati mereka yang miskin. Baik orang miskin dan orang kaya hidup di bawah kolong langit yang sama dan menerima hujan dan matahari yang sama. Pemahaman inilah yang sering disalah-artikan oleh para penguasa untuk menindas kaum miskin dan mengambil hak-haknya sehingga mereka semakin melarat.

Demikian halnya dalam PB, Yesus sangat menekankan kasih akan saudara seperti diri sendiri. Yesus menyuarakan untuk membebaskan orang-orang yang tertindas dengan memberitahukan tahun rahmat Tuhan sebagaimana yang Yesus kutip dari kitab para nabi (Luk 4:19). Dalam "khotbah di bukit" (Mat 5-7) Yesus mengajarkan supaya tidak perlu kuatir dan takut akan makanan dan minuman atau pakaian sebab kekuatiran yang demikian timbul oleh karena dosa. Tetapi Tuhan memelihara hidup setiap orang yang percaya. Bukan berarti tidak boleh kaya, tetapi kekayaan yang berlebih adalah lambang dari kesombongan dan

\footnotetext{
21 Suara kenabian ini harus selalu bergema sepanjang keumatan Allah hidup dan berinteraksi di dalam dunia ini. Christoph Barth, Teologia Perjanjian Lama 2, (Jakarta: BPK Gunung Mulia, 2001), h. 59.
} 
kecongkakan dan akar dari kejahatan atau dosa (Mat 6:21; 1 Tim 6:10). Tuhan sangat mengasihi semua ciptaan-Nya dan di dalam kasih itulah Dia menyatakan berkat-berkat yang melimpah bagi setiap orang yang percaya kepada-Nya. Artinya, Alkitab mengajarkan bahwa Tuhan memberkati setiap orang dan memberikan kemakmuran kepada siapa saja yang takut akan Dia (Ams 3:16). Pengangguran dan kemiskinan adalah ulah sebagian orang yang mengambil hak- hak orang lain, dan Tuhan sangat benci kepada perlakukan ketidakadilan. Dia menentang orang yang berbuat curang, tamak loba dan mengingini harta orang lain untuk kepentingan dirinya sendiri. Seperti Izabel dan Ahab yang mengingini harta/kebun Nabot (1 Raja 21:1-16). Penolakan Izabel adalah salah satu contoh yang layak untuk ditelaah, disamping suara kenabian yang disampaikan oleh para nabi dalam PL.

Penutup: Pengentasan Pengangguran, Kemiskinan dan Mewujudkan Keadilan Sosial.

Sesuai dengan perkembangan situasi dan tuntutan para kaum miskin/ duapa serta pengaruh dari dunia luar ada beberapa tanggapan utama yang sedang dikembangkan untuk menanggulangi kemiskinan: Pertama, bantuan kemiskinan atau membantu secara langsung kepada orang miskin. Ini telah menjadi bagian pendekatan dari masyarakat Eropa sejak abad pertengahan. Kedua, bantuan terhadap keadaan individu. Banyak macam kebijakan yang dijalankan untuk mengubah situasi orang miskin berdasarkan perorangan, termasuk hukuman, pendidikan, kerja sosial, pencarian kerja, dan lain-lain. Ketiga, persiapan bagi yang lemah. Daripada memberikan bantuan secara langsung kepada orang miskin, banyak negara sejahtera menyediakan bantuan untuk orang yang dikategorikan sebagai orang yang lebih mungkin miskin, seperti orang tua atau orang dengan ketidakmampuan, atau keadaan yang membuat orang miskin, seperti kebutuhan akan perawatan kesehatan. ${ }^{22}$

22 Hai ini sekaligus kritik terhadap apa yang dilakukan pemerintah dalam beberapa periode kepemimpinan yang selalu berupaya "memanjakan" rakyat dengan memberikan bantuan langsung tunai, tentu bermanfaat walau untuk sejenak namun sama sekali tidak mengedukasi apaapa.
Usaha lain yang dilakukan adalah dengan melakukan transmigrasi, walaupun usaha itu tidak sepenuhnya bisa menolong transmigran. ${ }^{23}$ Sebab ternyata banyak faktor yang memengaruhi proses pelaksanaan upaya pemerataan penduduk dengan transmigrasi, misalnya kemauan yang kecil oleh masyarakat, fasilitas dan keadaan daerah transmigrasi yang sangat memrihatinkan dan lain sebagainya. Semua hal yang positif yang dikaji dan dikembangkan pemerintah untuk mengatasi kemiskinan seharusnya mendapat dukungan. Tetapi apa yang sudah dilakukan ternyata masih belum menunjukkan perkembangan yang signifikan terhadap perbaikan ekonomi mikro dan makro yang diharapkan berpengaruh kepada menurunnya angka pengangguran dan kemiskinan.

Sebaiknya untuk usaha-usaha tersebut, kita kembali merenungkan apa yang Tuhan dambakan dalam penciptaan dunia ini. Tidak akan ada perbedaan status sosial dan kemiskinan tidak akan menjadi masalah yang sulit jika masing-masing pihak terbuka dan memberikan diri untuk saling memperbaiki. Selain upaya pemerintah meningkatkan pertumbuhan ekonomi, memperbaiki keadaan dan menciptakan lapangan kerja yang memadai untuk angkatan kerja produktif, kita juga harus lebih mampu mengolah sumber daya alam yang ada untuk menopang perekonomian pribadi. Misalnya dengan usaha yang sederhana namun tepat guna dan sesuai dengan permintaan pasar. Artinya dapat menciptakan lapangan kerja sendiri sesuai dengan hukum yang Tuhan berikan (Kej 3:17-19), sehingga penganguran bukanlah suatu mimpi buruk yang ditakuti.

Kalaulah kepemilikan lahan pertanian dan perkebunan sudah jatuh kepada golongan elit dan penguasa, maka pemerintah harus lebih terbuka untuk mengatasi penguasaan lahan secara sepihak dan mengembalikan kepada rakyat apa yang menjadi hak mereka. Denmikian halnya setiap pengusaha dan kaum elit sebaiknya harus membuka diri untuk melihat

\footnotetext{
${ }^{23}$ Gustav Papenak, "Penduduk Miskin di Jakarta", h. 265. Sekitarnya dan memedulikan kaum miskin dan melarat tersebut. Suara kenabian seperti itu harus senantiasa disampaikan oleh gereja untuk membantu para kaum miskin.
} 
Selain itu, perlu ada jaminan perlindungan hukum dan pembelaan hak- hak kaum miskin (advokasi) sekaligus meningkatkan kemampuan untuk menggali potensi di tengah-tengah masyarakat seperti membangun usaha mikro dalam "Credit Union" (CU). Usaha ini diharapkan akan membantu dan mendorong warga gereja untuk bangkit, berusaha dan berjuang memertahankan hidupnya di tengah keadaan saat ini. Artinya, pengangguran dan kemiskinan tidak perlu dihindari tetapi dihadapi. Sebab pengangguran dan kemiskinan tidak menakutkan. Hanya perlu lebih ditingkatkan lagi kesadaran untuk memperbaiki ekonomi, sosial dan pendapatan dengan usaha sendiri, dengan meningkatkan kemampuan dan pendidikan atas keadaran sendiri. Inilah tugas dan tanggung jawab gereja dalam menghadapi persoalan sosial yang serba sulit saat ini. Gereja tidak hanya bersuara melalui mimbar dengan kotbah atau dengan orasi-orasi yang menantang dan bersemangat, akan tetapi gereja harus lebih membuka diri dan turun ke lapangan melihat dan merasakan penderitaan kaum miskin.

Pengangguran, kemiskinan dan mewujudkan keadilan sosial bukan hanya tugas pemerintah, tetapi juga tugas yang harus dihadapi oleh semua kalangan. Kita harus jujur dan terbuka untuk mencari solusi dan jalan keluar dari persoalan tersebut. Kalau angka pengangguran semakin tinggi dan tingkat kemiskinan tetap meningkat; sebagai warga kerejaan Allah di tengah- tengah dunia ini marilah kita bekerja saling tolongmenolong menyatakan damai sejahtera Allah dan menjaga diri untuk tetap setia dan bertahan dalam keadilan Allah. ${ }^{24}$

\footnotetext{
24 Perlu diingatkan bahwa Konfrensi Dunia yang pertama (1925) di Stockholm, Swedia yang nantinya sebagai cikal-bakal pembentukan Dewan Gereja Dunia (DGD) mengambil tema Life and Work. Tema ini berkenaan dengan kesadaran implikasi Injil untuk kehidupan dan pekerjaan sehari-hari, kehidupan sosial bersama. Menghadirkan Kerajaan Allah dalam keseharian hidup, di semua lapangan kehidupan manusia.
}

Memberikan perhatian, kepedulian dan kepekaan terhadap masalah-masalah sosial khususnya dalam pengangguran dan kemiskinan. Ini adalah tugas bersama, khususnya sebagai orang percaya kita terpanggil untuk menyatakan berkat dan menyuarakan suara kenabian dari Tuhan sebagai gereja yang hidup di tengah-tengah dunia ini.

\section{Daftar Pustaka}

Badudu, J.S. dan S.N.Zain, Kamus Umum Bahasa Indonesia, (Jakarta: Sinar Harapan, 1996).

Barth, Christoph, Teologia Perjanjian Lama 2, (Jakarta: BPK Gunung Mulia, 2001).

Barth, Karl, Church Dogmatics (IV), (Edinburgh: T\&T Clarck Ltd., 1962).

Cairns, I.J., Perjanjian Lama dan Indonesia yang Sedang Membangun, (Jakarta: BPK Gunung Mulia, 1999).

Kuntjoro-Jakti, Dorodjatun

(ed.), Kemiskinan di Indonesia (Jakarta: Yayasan Obor Indonesia, 1986).

Nainggolan, Binsar, Pengantar Etika Terapan, (Pematang Siantar: LSAPA, 2007).

Oberai, A.S., State Policies and Internal Migration: Studies in Market and Planned Economies (London: Croombelm, 1985).

Panjaitan, Merphin, Memberdayakan Kaum Miskin, (Jakarta: BPK Gunung Mulia, 2002).

Simatupang, Pantjar dan Saktyanu K. Dermoredjo, Produksi Domestik Bruto, Harga, dan Kemiskinan, dalam Media Ekonomi dan Keuangan Indonesia, Vol. 51 No. 3 , h. 191-324.

Simon dan Christoper Danes, Masalahmasalah Moral Sosial Aktual dalam PerspektifIman

Kristen,

(Yogyakarta: Kanisius, 2000).

Stott, John, Isu-isu Global, (Jakarta: YKBK/OMF, 2010). 